\title{
Gene Therapy With Regulatory T Cells: A Beneficial Alliance
}

\author{
Moanaro Biswas ${ }^{1 *}$, Sandeep R. P. Kumar ${ }^{1}$, Cox Terhorst ${ }^{2}$ and Roland W. Herzog ${ }^{1}$ \\ ${ }^{1}$ Division of Cellular and Molecular Therapy, Department of Pediatrics, University of Florida, Gainesville, FL, \\ United States, ${ }^{2}$ Division of Immunology, Beth Israel Deaconess Medical Center (BIDMC), Harvard Medical School, \\ Boston, MA, United States
}

\section{OPEN ACCESS}

Edited by:

Herman Waldmann,

University of Oxford,

United Kingdom

Reviewed by:

David William Scott,

Uniformed Services University of the Health Sciences, United States Bruce Milne Hall, University of New South Wales, Australia

*Correspondence: Moanaro Biswas narobiswas@ufl.edu

Specialty section: This article was submitted to Immunological

Tolerance and Regulation, a section of the journal

Frontiers in Immunology

Received: 06 August 2017 Accepted: 05 March 2018 Published: 19 March 2018

Citation:

Biswas M, Kumar SRP, Terhorst C and Herzog RW (2018) Gene Therapy With Regulatory T Cells: A Beneficial Alliance.

Front. Immunol. 9:554. doi: 10.3389/fimmu.2018.00554
Gene therapy aims to replace a defective or a deficient protein at therapeutic or curative levels. Improved vector designs have enhanced safety, efficacy, and delivery, with potential for lasting treatment. However, innate and adaptive immune responses to the viral vector and transgene product remain obstacles to the establishment of therapeutic efficacy. It is widely accepted that endogenous regulatory $T$ cells (Tregs) are critical for tolerance induction to the transgene product and in some cases the viral vector. There are two basic strategies to harness the suppressive ability of Tregs: in vivo induction of adaptive Tregs specific to the introduced gene product and concurrent administration of autologous, ex vivo expanded Tregs. The latter may be polyclonal or engineered to direct specificity to the therapeutic antigen. Recent clinical trials have advanced adoptive immunotherapy with Tregs for the treatment of autoimmune disease and in patients receiving cell transplants. Here, we highlight the potential benefit of combining gene therapy with Treg adoptive transfer to achieve a sustained transgene expression. Furthermore, techniques to engineer antigen-specific Treg cell populations, either through reprogramming conventional $\mathrm{CD}^{+}{ }^{+} \mathrm{T}$ cells or transferring $\mathrm{T}$ cell receptors with known specificity into polyclonal Tregs, are promising in preclinical studies. Thus, based upon these observations and the successful use of chimeric (lgG-based) antigen receptors (CARs) in antigen-specific effector T cells, different types of CAR-Tregs could be added to the repertoire of inhibitory modalities to suppress immune responses to therapeutic cargos of gene therapy vectors. The diverse approaches to harness the ability of Tregs to suppress unwanted immune responses to gene therapy and their perspectives are reviewed in this article.

Keywords: regulatory $\mathrm{T}$ cells, tolerance, gene therapy, chimeric antigen receptor regulatory $\mathrm{T}$ cells, adoptive transfer, cell therapy, adeno-associated virus vectors, lentiviral vectors

\section{INTRODUCTION}

Gene therapy has the tremendous potential to completely cure with a single treatment, diseases previously classified as untreatable, or disorders that could be managed but not corrected. Correction is achieved by transferring a functional copy of a gene, which is otherwise mutated in the diseased state, or by editing the defective gene in the patient's body. After a period of major setbacks during the late 1990s and early 2000s, this technique has reemerged as a major breakthrough in regenerative medicine $(1,2)$. A clear proof of clinical efficacy has mostly been observed in ocular diseases (inherited blindness), primary immune deficiencies, beta-hemoglobinopathies, and more recently hemophilia (2-9). Approaches for gene therapy in the clinic are based on in vivo delivery 
to post-mitotic cells or tissues, or ex vivo delivery into autologous hematopoietic stem cells (HSCs), followed by reinfusion into the patient. Treatment of blindness by in vivo gene transfer (NCT00999609 and NCT00516477) is the first representative gene therapy drug approved in the USA by the Food and Drug Administration (Luxturna, Spark Therapeutics). In the meantime, cancer gene therapy drugs have already been approved, which include the virotherapeutic Imlygic (an engineered oncolytic Herpes virus, Amgen), chimeric antigen receptor (CAR) T cell therapy such as tisagenlecleucel-T (Kymriah, Novartis), and most recently, axicabtagene ciloleucel (Yescarta, Kite Pharma). The latter are of particular significance for this review, as they underscore the potential for therapies based on genetically engineered T cells.

\section{IMMUNE RESPONSES TO GENE THERAPY}

The aim of successful gene therapy is the safe and effective delivery of the replacement gene at therapeutic levels, potentially for the lifetime of an individual. A key obstacle to successful gene therapy is the host's immune response to both the viral vector and the transgene product. A fatal inflammatory immune response to the adenoviral vector almost brought the field to a stop in 1999 in a gene therapy clinical trial (10), although the safety and efficacy of gene therapy has been clearly established since then.

Gene therapy by vector administration into immune-privileged sites like the brain, eye, and testis has successfully achieved longterm transgene expression $(11,12)$. However, vector-mediated delivery into immune-competent organs is complicated by prevailing neutralizing antibodies that can limit the efficacy of transduction in patients (13). Although initial trials enrolled patients after a very careful selection process, gene therapy is becoming more common, and patient inclusion criteria are expected to be less exclusive, likely including patients with prevailing neutralizing antibodies or cross-reactive immunologic material- negative mutations.

At present, several viral vectors have been established as vehicles for gene transfer. Common among these are adenoviral vectors, gamma retroviral vectors, adeno-associated virus (AAV) vectors, and lentiviral vectors (LVs). For LV, gene therapy has been clinically approved for ex vivo gene transfer $(14,15)$, and the use of LVs for in vivo gene replacement is being evaluated in preclinical models $(16,17)$. This is facilitated by the low prevalence of neutralizing antibodies to LVs and the capacity to accommodate larger gene inserts. The new generation of replication-deficient vectors is gutted and nonpathogenic. Unlike gamma-retroviruses that favor integration near transcription start sites, LVs have been shown to integrate into active genes, making the chances of insertional mutagenesis and clonal expansion less likely (18). Potential innate and adaptive immune responses, which vary in magnitude, can develop toward the encoded transgene (19), envelope pseudotype or proteins acquired during the packaging process (20). LV-triggered innate immune responses such as type I IFN are primarily mediated by viral genome engagement with TLRs, possibly TLR9 and TLR7 (21-23).
Cytotoxic T lymphocyte (CTL) responses to both viral antigen and transgene have been observed with early-generation adenovirus and in preclinical models of in vivo adenoviral gene transfer (24-26). Replication-deficient, first- and secondgeneration adenovirus vectors are now being used in cancer gene therapy clinical trials, particularly for solid cancers (NCT01811992, NCT02630264, NCT01310179, NCT00870181 and NCT01147965). The high immunogenicity of adenoviral vectors has also made them attractive candidates as vaccine carriers. For example, the recent devastating outbreak of Ebola prompted a rapid phase I clinical trial of the replication-defective, chimpanzee adenovirus type 3 -vectored Ebola virus vaccine (cAd3-EBO) (27). There is interest in helper-dependent or gutless third-generation adenoviral vectors, because of reduced in vivo immune responses as compared to first- and second-generation adenoviral vectors (28). However, innate immune responses are still elicited (29).

For in vivo gene delivery, recombinant AAV is the vector of choice due to its ease of construction, wide tissue tropism, and presumed lack of pathogenicity as it does not efficiently transduce macrophages, mature DC, and other antigen-presenting cells (APCs), although endocytosis of AAV has been associated with innate immune activation (30). It has been shown that the TLR9-MyD88 pathway is crucial for cross priming AAV capsid-specific $\mathrm{CD}^{+} \mathrm{T}$ cells, a process that requires the cooperation of both pDC and CDC subsets of dendritic cells, as well as for activating transgene-specific $\mathrm{CD} 8^{+} \mathrm{T}$ cell responses $(31,32)$. Anti-capsid effector $\mathrm{T}$ cell responses have been elicited in trials where the vector was administered outside of the retina or CNS. These have been shown to be responsible for deleterious immune responses against transgene-expressing cells, affecting therapeutic efficacy (33-36). Anti-capsid effector $\mathrm{T}$ cell responses were not predicted by preclinical studies, highlighting one of the major preclinical challenges when working with AAV (34).

\section{Treg TYPES AND CHARACTERISTICS}

The molecular characteristics that enable Tregs to modulate the activation of responder $\mathrm{T}$ cells render them uniquely suitable to limit immune responses to a therapeutic gene. Tregs have potent immunosuppressive properties that can be harnessed to confer antigen-specific immunomodulation in a therapeutic setting (37). Treg activity is required to maintain immune homeostasis in the presence of autoreactive $\mathrm{T}$ cells. Thus, they have defined roles in diverse clinical conditions including cancer, autoimmune disease, and transplant rejection (38-40). The most commonly studied among them are the $\mathrm{CD} 4{ }^{+} \mathrm{CD} 25^{+} \mathrm{FoxP} 3^{+}$-expressing Treg subset, which are thymus-derived and called thymic, natural, or central Tregs (41). Natural Tregs commonly exhibit specificity to self-antigen and are essential for maintaining tolerance to self-tissues. Treg cells derived from outside the thymus are often referred to as induced, adaptive, or peripheral Tregs. These can be antigen-specific effector T cells induced to express FoxP3, or type 1 Treg $(\operatorname{Tr} 1)$ cells that are FoxP3-, express surface LAG-3 (CD223) and CD49b, and secrete IL-10 $(42,43)$. A recent FoxP3subset, with a regulatory activity, expressing latency-associated peptide (LAP) on the surface as latent TGF- $\beta$ complexes has also 
been defined, which can be cleaved to release active TGF- $\beta$ (44). Nonetheless, there is scientific consensus that each Treg subset has suppressive capacity and is integral to maintaining tolerance, as has been observed in treatment for autoimmune diseases and in gene therapy.

Resting natural Tregs are usually CD25 ${ }^{\text {hi }}$, CD $127^{-}$, L-selectin $(\mathrm{CD} 62 \mathrm{~L})^{+}$, CTLA-4 $(\mathrm{CD} 152)^{+}$, and $\mathrm{ICOS}^{ \pm}$. Other natural Treg markers such as neuropilin are specific for mice $(45,46)$. The activation of both natural and peripherally induced Tregs (iTreg) is associated with inducible upregulation of markers, many of which are not Treg exclusive, but are common in activated effector and memory T cells. These include but are not limited to CD69, CD25, CD44 (47, 48), CD39, and CD73 (49), galectin-1 and -10 $(50,51)$, glycoprotein A repetitions-predominant (GARP) and LAP (52, 53), CTLA-4 (CD152) (54), Ki67, GITR (TNFRSF18), TNFR2, and ICOS (55). In particular, CTLA-4 has been found to regulate many aspects of Treg suppression and can control the progression of autoimmune disease (56-59). In some cases, activated Tregs have been associated with an increase in FoxP3 expression (60-62).

Regulatory $\mathrm{T}$ cell suppressive function has been shown to be primarily TCR contact-dependent. TCR signaling is crucial for Treg development, differentiation, and suppressive function (63). Tregs use multiple mechanisms to suppress immune responses, depending on the nature and tissue-specific location of the antigen (lymphoid and non-lymphoid tissues). These include antigen-specific and bystander suppression associated with the release of cytokines such as IL-10, TGF- $\beta$, and IL-35 (64), IL-2 deprivation, direct cell killing (65), the production of metabolic intermediates $(66,67)$, and the modulation of dendritic cell maturation and stimulatory function $(68,69)$.

\section{EVIDENCE THAT Tregs LIMIT IMMUNE RESPONSES IN MUSCLE GENE TRANSFER}

Gene delivery into the muscle is attractive as a potential source for therapeutic protein expression. Muscle gene therapy is ideal for degenerative disorders like the muscular dystrophies, storage disorders leading to metabolic myopathy such as Pompe disease or for the production of enzymes like alpha- 1 antitrypsin (AAT) (70). A major barrier to muscle gene transfer is the need to deliver the replacement gene body wide, necessitating multiple injections into various sites throughout the body, thereby increasing the potential for inflammatory immune responses $(71,72)$. Further, the often-required high vector doses also enhance the risk of provoking an immunological response. Physiologically, delivery into the muscle environment causes inflammation, presumably due to the high frequency of resident macrophages.

Clinical trials using muscle gene transfer have shown promise for many disorders, some of which show very poor prognosis with conventional therapy. For example, gene replacement therapy is a feasible approach for the treatment of the lysosomal storage disorder, Pompe disease, which particularly affects the skeletal and cardiac muscle, and neural tissues. Initial clinical experience in Pompe disease shows that the direct delivery of AAV1-hGAA into the diaphragms of affected children is safe, well tolerated, and efficacious $(73,74)$. Neutralizing antibody development against the hGAA transgene product and the viral vector prevents therapeutic efficacy and vector readministration, respectively $(75,76)$. Interestingly, T cell reactivity toward the vector has not been observed to date (73). Preclinical data show that lentiviral correction of HSCs by ex vivo transduction was effective in ameliorating Pompe disease in a mouse model (77), which could be a viable alternative for preventing immune responses by facilitating central tolerance.

The detection of $\mathrm{T}$ cell responses to the capsid in peripheral blood mononuclear cells is not always associated with a deleterious immune response, as seen during gene transfer trials with AAT. Despite the detection of T cell reactivity against the vector and infiltrates into the treated muscle, the transgene was still expressed in subjects who received an AAV1 vector encoding for AAT (78-81). Interestingly, $\mathrm{CD} 4^{+} \mathrm{CD} 25^{+} \mathrm{FoxP} 3^{+}$Tregs were found within the infiltrating cells $(\sim 10 \%)$ in vector-injected muscle and were associated with a time-dependent decrease in muscle inflammation, which may have prevented the destruction of transduced myofibers (82).

Similarly, a population of Tregs was shown to accumulate in muscles of dystrophic mice and in muscle biopsies from Duchene muscular dystrophy (DMD) patients $(83,84)$. These IL-10-secreting Tregs improved the dystrophic phenotype by decreasing inflammation associated with the disease, and their depletion resulted in worsening of the disease phenotype. Therapeutic targeting of Tregs with IL-2/anti-IL-2 complexes had a beneficial effect of reducing muscle inflammation and injury in dystrophic mice. Thus, these observations demonstrate the potential of Treg-modulating agents to induce a local Treg population in muscle at the time of gene transfer to reduce muscle inflammation and favor the maintenance of transgene expression in DMD. Another feasible alternative is adoptive immunotherapy with polyclonally expanded or antigen-specific Tregs at or during the time of gene therapy. In an earlier pivotal study, the administration of exogenous transgene-specific Tregs concomitantly with AAV gene transfer was shown to lower anti-transgene immune reactivity and allow stable transgene expression in normal muscle (85). This established that adoptively transferred $\mathrm{CD} 4{ }^{+} \mathrm{CD} 25^{+}$regulatory $\mathrm{T}$ cells can induce a sustained transgene engraftment in solid tissues. Combinatorial treatments using adoptive Treg transfer as adjunct therapy may thus enhance the therapeutic effect of gene delivery by developing tolerance toward the gene delivery vehicle or transgene product.

\section{THE LIVER AS AN IDEAL SITE FOR IMMUNE REGULATION}

The administration of gene therapy systemically leads to rapid accumulation of high levels of vector particles within the liver. Specialized liver-resident cells mediate the "liver tolerance effect," which establishes local and systemic tolerance to self and foreign antigens. This has been attributed to the expression of inhibitory 
cell surface ligands for $\mathrm{T}$ cell activation and the production of anti-inflammatory mediators (86).

The utilization of liver tropic viruses, engineered vector serotypes, and liver-specific promoter and enhancer elements have improved liver gene delivery and increased gene expression to clinically therapeutic levels (87). Much of the present interest in the development of liver-directed gene therapy stems from recent clinical success in treating the $\mathrm{X}$-linked coagulation disorder hemophilia B, with restoration of clinical levels of factor IX (FIX) to hemophilia B patients for sustained periods greater than 5 years $(7,36)$. A transient increase in liver enzymes, presumably due to the reactivation of a memory CTL response to the vector, was earlier observed, although intervention with corticosteroid administration at the first sign of hepatocellular injury could halt the increases in liver enzymes and sustain FIX expression (34). Similarly, high endogenous levels of clotting factor have been reported in recent clinical trials for both hemophilia A and B $(88,89)$.

The development of inhibitory antibodies that neutralize factor VIII (FVIII) or FIX is a major complication of protein replacement therapy as well as gene therapy for patients with hemophilia (90). Preclinical studies in small and large animal models of hemophilia have demonstrated that gene therapy strategies and the continuous exposure to clotting factor can promote tolerance and eradicate preexisting antibodies (91-94). Nonetheless, there is still a risk of developing neutralizing antibodies to the coagulation factor product following hepatic gene transfer (95). There is strong evidence that Tregs are an important element of the mechanism by which self-tolerance is maintained and inhibitor development, a $\mathrm{T}$ helper-dependent response, is prevented (96-99). In many cases, immune tolerance to hepatic gene transfer of hFIX has also been associated with the induction of Tregs (100-102). We propose that the adoptive transfer of Tregs in the setting of liver gene therapy has the potential to avoid the general immunosuppression that many corticosteroid drugs pose, instead favoring tolerance to the transgene in an antigen-specific, safe, and transient manner.

Another field where liver gene therapy has garnered interest is in the treatment of autoimmune disorders like rheumatoid arthritis, multiple sclerosis, and type 1 diabetes (T1D). Replacement gene delivery in these cases is complicated by the development of an immune response to the therapeutic gene. Studies have demonstrated that gene therapy into the tolerogenic liver microenvironment can abrogate the development of experimental autoimmune encephalomyelitis (EAE) even if the target antigen for the inflammatory $\mathrm{T}$ cell response is in a distant organ, such as the central nervous system $(103,104)$. Protection from EAE was dependent on the induction of antigen-specific $\mathrm{CD}^{+} \mathrm{CD} 25^{+} \mathrm{Foxp}^{+}$Tregs $(103,104)$. Using the same principle in a preclinical mouse model T1D, Akbarpour et al. showed that targeting LV-mediated insulin gene expression to hepatocytes induced regulatory $\mathrm{T}$ cells specific for insulin, which halted immune cell infiltration into the pancreatic islet and protected from T1D (105). Thus, it appears that targeting gene transfer to hepatocytes can favor the induction of antigen-specific Tregs systemically, making the liver an attractive target for achieving transgene tolerance.

\section{IN VIVO TOLERANCE INDUCTION WITH Treg}

Given the critical role of Treg in maintaining immune regulation of transgene-specific responses, an obvious treatment of choice is the in vivo induction of antigen-specific Treg by a specific or a combination drug treatment. Global immune suppression by steroid or chemotherapeutic drugs, while beneficial when given transiently, does not have the advantage that a more targeted and a lasting transgene product-specific Treg response can offer. One method of inducing Treg is to coadminister the antigen with the macrolide immunosuppressant rapamycin (sirolimus), which inhibits cell cycle progression of activated $\mathrm{T}$ cells by mTOR pathway blockade, leading to T cell anergy or deletion (106). At the same time, the inhibition of the T cell stimulatory activity of dendritic cells (107) and mTOR-independent signaling by Tregs (108) result in the enrichment of antigen-specific $\mathrm{CD}^{+}{ }^{+} \mathrm{CD} 25^{+} \mathrm{FoxP}^{+}$Treg (109-111). This effect can be enhanced by the addition of cytokines such as IL-10 or Flt3L, which have been shown to promote tolerance in protein replacement therapy $(96,99)$. Prophylactic therapy of IL-10 in combination with rapamycin and antigen has also been successful in the prevention and reversal of inhibitory antibody responses in muscle gene transfer of therapeutic FIX in hemophilia B mice $(96,99,112)$. Likewise, the introduction of rapamycin with liver gene therapy resulted in a markedly enhanced expression of human acid- $\alpha$-glucosidase in nonhuman primates, likely due to the induction of hepatic autophagy and is being evaluated for readministration of the AAV vector (113).

Tolerance to antigens administered by the oral route is another approach to inhibit antigen-specific immune responses by targeting the gut-associated lymphoid tissue (114). Multiple immune cell types have been shown to be involved in mediating this state of non-responsiveness, including gut resident dendritic cells, FoxP3 $3^{+}$Tregs and $\mathrm{CD}^{+} \mathrm{CD} 25^{-} \mathrm{LAP}^{+}$-expressing Tregs (115-117). Gut homing receptors and cytokines such as TGF- $\beta$ and IL-10 have been shown to be responsible for the infiltration/ differentiation/local expansion of these Treg subtypes and the induction of tolerance (118). Significantly, oral tolerization improved long-term transgene persistence and expression as shown in a recent study using AAV-mediated gene transfer of the model antigen OVA (119).

\section{CELLULAR THERAPY WITH Treg}

Extensive preclinical studies have demonstrated that Tregs play a key role in both the induction and maintenance of tolerance. Adoptive immunotherapy with autologous or donor Tregs has shown promise in several clinical trials for autoimmune disorders and in transplant conditions $(120,121)$. With new GMP protocols in place, $\mathrm{FoxP}^{+}$Tregs can undergo polyclonal or antigen-specific expansion with high purities $(122,123)$. Protocols to generate donor-specific $\operatorname{Tr} 1$ cells are also well established (124-126). Clinical trials with freshly isolated or ex vivo expanded FoxP3 ${ }^{+}$ (127-130) or Tr1 cells (ALT-TEN trial) (131) (from umbilical cord blood or peripheral blood) as a cellular therapy given at 
or shortly before/after transplantation have been carried out for tolerance to graft-versus-host disease (GvHD) in patients undergoing allo-HSCT for hematological malignancies. Alternatively, ultra-low-dose (ULD) IL-2 has been suggested to selectively expand nTreg in vivo, suppressing alloreactive responses in GvHD prophylaxis and treatment (132-134). Supplementing Treg infusion with ULD IL-2 to promote Treg persistence and survival for the treatment of onco-hematological diseases is being tested (NCT02991898).

Studies testing the safety and feasibility of autologous polyclonal or alloantigen-specific Treg infusion for conferring tolerance in solid organ transplantation are currently ongoing [NCT02145325 (TRACT), NCT02088931, NCT02711826 (TASK), UMIN000015789] (135). The ThRIL study (NCT02166177) has been initiated to evaluate the efficacy of Treg cell therapy, in combination with immune-suppressive drugs, in liver-transplant recipients.

The ONE Study (www.onestudy.org) is a phase I/IIa clinical trial aimed at testing the safety and feasibility of seven different regulatory $\mathrm{T}$ cell populations in living donor kidney transplants. This multicenter study compares autologous ex vivo expanded polyclonal $\mathrm{CD}^{+} \mathrm{CD} 25^{+}$nTregs from peripheral blood, Tr1 cells, donor alloantigen-driven Tregs (darTreg), and alloantigen-driven $\mathrm{T}$ cells anergized by costimulation blockade, tolerogenic dendritic cells, and regulatory macrophages (Mregs). Comparisons will be made between patients receiving standard immunosuppressive treatment (basiliximab followed by tacrolimus, mycophenolate mofetil, and prednisolone) and those receiving immunotherapy (136).

Finally, Treg therapy has also been applied to autoimmune and inflammatory disorders (e.g., TRIBUTE trial for Crohn's). An autologous antigen-specific $\operatorname{Tr} 1$ therapy for refractory Crohn's disease is in development (Ovasave, Txcell). In a study of pediatric patients with T1D, single and repeat infusions of polyclonal expanded Tregs were found to be safe and effective in patients (137). As with GvHD, the effect of low-dose IL-2 on in vivo induction of Tregs for 12 autoimmune and inflammatory diseases is being tested in a multicentric trial (TRANSREG, NCT01988506). Moreover, studies to assess the safety of Treg immunotherapy supplemented with IL-2 and the persistence of infused autologous Tregs in patients with recent onset T1DM are being undertaken (TILT study, NCT02772679) (138). In an earlier report by the same group, a study of 14 adult subjects with T1D who received ex vivo expanded polyclonal Tregs saw a subset of Tregs remaining in circulation at 1 year after transfer (139).

Taken together, these studies reveal that infusions of ex vivo expanded FoxP3 $3^{+}$or FoxP3- $(\operatorname{Tr} 1)$ cells are safe, well tolerated, and can aid in tolerance in many inflammatory and autoimmune conditions.

\section{SUPPLEMENTING GENE THERAPY WITH Treg ADOPTIVE TRANSFER}

The immune suppressive properties of Tregs have generated interest in utilizing this cell population for tolerance toward the transgene product. Not only are Tregs critical for establishing central tolerance during development and in preventing autoimmunity, they are also involved in inducing tolerance toward exogenous antigens, such as therapeutic proteins. Ideally, immune modulation to suppress vector or transgene-specific responses should eliminate undesired immune cells while sparing protective immunity.

There is ample evidence that adoptive immunotherapy with polyclonal or engineered Tregs can improve protein replacement therapy in inherited protein deficiencies (98). On the other hand, very few studies on infusing Tregs to improve tolerance to gene therapy have been carried out. So far, gene therapy into immune privileged sites like the eye has not been associated with a deleterious immune response. Likewise, gene delivery into tolerogenic organs, particularly the liver, has in fact been shown to induce Tregs in vivo. However, liver-directed gene therapy, while successfully diminishing immune responses toward the transgene product, does not completely eliminate the development of cytotoxic $\mathrm{T}$ cells that can subsequently lead to the potential immune-mediated deletion of transgene-expressing cells (140). Similarly, although the development of neutralizing antibodies to the transgene product has so far not been observed in the small number of liver gene therapy clinical trials in humans, the possibility remains a concern as observed in preclinical studies for the immunogenic FVIII molecule $(140,141)$ (unpublished observations). Strategies such as using microRNA target sequences (miR-142-3p) in the LV to de-target transgene expression from professional APCs, coupled with restricted expression in either hepatocytes or liver endothelial cells, have led to improved transgene expression. This has been shown to correlate with the emergence of transgene-specific Tregs, which induced tolerance in preclinical models of hemophilia A and B $(17,142,143)$.

In an earlier study on complementing gene therapy with Treg adoptive transfer, Gross et al. established that the injection of influenza hemagglutinin (HA)-specific $\mathrm{CD} 4{ }^{+} \mathrm{CD} 25^{+}$Tregs, concomitant with gene transfer, enabled persistent HA transgene expression in the muscles of mice (85). Cytotoxic T cell responses, as well as circulating anti-IgG antibodies to HA, were impaired in HA-Treg recipients. These findings were applied to a disease setting for hemophilia A, where nonviral gene transfer of the therapeutic FVIII plasmid resulted in supraphysiological levels of FVIII, but triggered inhibitory antibody development and loss of functional FVIII activity. Adoptive transfer of cells enriched for FVIII-specific Tregs into naïve hemophilic mice, followed by plasmid challenge, led to a significantly diminished inhibitory antibody formation for a prolonged period, as compared to control animals (144). These studies establish the potential of Tregs to modulate immune responses to the transgene product in an antigen-specific manner (Figure 1). Our group added to these initial studies by demonstrating that adoptively transferred ex vivo expanded Treg could be used to improve gene therapy of FIX in a mouse model of hemophilia B (98). In the study, polyclonal ex vivo expanded autologous $\mathrm{CD} 4^{+} \mathrm{CD} 25^{+} \mathrm{FoxP} 3^{+}$Treg administered at doses similar to those currently used in clinical trials $\left(\sim 5 \times 10^{7}\right.$ cells $\left./ \mathrm{kg}\right)$ was able to prevent the formation of an adaptive immune response in hemophilia $B$ mice receiving AAV1 hFIX muscle directed gene transfer. Despite limited in vivo persistence of the adoptively transferred cells, a sustained 


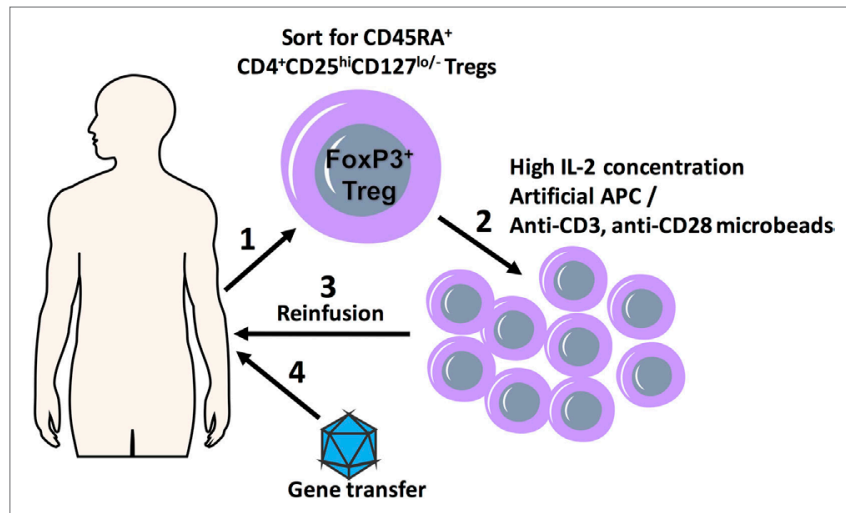

FIGURE 1 | A scheme detailing combination regulatory T cell (Treg) adoptive therapy with gene transfer for tolerization of immune responses. FoxP3 ${ }^{+}$Treg cells with polyclonal specificity are harvested from the patient (1) and ex vivo expanded in the presence of high IL-2 concentrations and artificial APC (aAPC) or anti-CD3, anti-CD28 microbeads using GMP protocols (2); expanded Tregs are transplanted back into the patient (3), which is followed shortly by gene transfer (4).

suppression lasting 10 weeks was observed. This was attributed to the emergence of antigen-specific suppression via the induction of endogenous Treg, which was facilitated by the transplanted Treg (Figure 2A). It has been shown that ex vivo expansion improves the suppressive properties of polyclonal Tregs, rendering them functionally superior to freshly isolated Tregs (145). Expanded Tregs highly upregulate CTLA-4 expression, which competes with the costimulatory molecule CD28 for binding to CD80/86 on APCs. Suboptimally activated APCs facilitate the induction of iTreg cells $(57,146)$.

Although cell therapy with expanded polyclonal Tregs has many advantages, it has been demonstrated that antigen-specific Tregs are more potent at 10- to 100-fold lower frequencies (147). One way to recover a sufficient number of antigen-specific Tregs is to expand them in the presence of alloantigens through a process of indirect allospecificity. This has been successfully used to promote transplantation tolerance, by expanding the recipient's Treg pool toward donor antigens (148-151). In some cases, Treg expansion and therapeutic potential were improved by the addition of IL-2 and IL-12 (152). However, it is unclear whether it would be possible to isolate rare antigen-specific Tregs to supplement gene therapy, especially in the case of inherited protein deficiencies, where the antigen is not expressed and central tolerance may not be achieved.

\section{THERAPY WITH GENETICALLY MODIFIED CELLS}

More recently, the applicability of gene therapy has moved beyond gene correction to a wider spectrum of diseases. Genemodified cells, such as CAR-modified T cells for the eradication of hematologic cancers, have achieved breakthrough success in clinical trials (153-156). Glaxo Smithkline has introduced the first ex vivo stem cell gene therapy to treat patients with ADASCID, Strimvelis, which received approval from the European
Medicines Agency in 2016 (157). Zalmoxis, a donor cell-derived $\mathrm{T}$ cell therapy used for H-SCT, is also poised for the market. These novel and successful trials are making way for other cutting-edge technology, such as the development of gene-editing techniques using CRISPR-Cas to increase the stability of CAR-T cells (NCT03166878) or for treating hematological malignancies in patients with HIV (NCT03164135).

Gene modification to increase antigen specificity has been recently applied to Tregs. The difficulty of isolating cells with a rare antigen specificity from the natural polyclonal $\mathrm{T}$ cell repertoire has hampered the clinical translation of targeted therapy with antigen-specific Tregs. On the other hand, treatment with polyclonally expanded Tregs requires the infusion of large numbers of clinical-grade autologous cells, with a possibility for general immunosuppression. Using clinical-grade LVs to genetically reprogram cells represents an attractive strategy to fine-tune Treg populations for a particular specificity (Figure 2B). One example is the ectopic overexpression of FoxP3 in conventional $\mathrm{CD}^{+}$ $\mathrm{T}$ cells from healthy donors, with the aim of generating a large number of homogeneous and functional Treg cell populations. This technique has been applied successfully to conventional $\mathrm{CD}^{+} \mathrm{T}$ cells of patients with immune dysregulation, polyendocrinopathy, enteropathy, X-linked (IPEX) syndrome (dysfunction in FoxP3 gene), and in other preclinical animal models of autoimmunity (158-161). The possibility of reversion to an effector $\mathrm{T}$ cell phenotype is a concern, given the plastic nature of many Treg populations. However, adoptively transferred, FoxP3 overexpressing Tregs were shown to be stable in steady-state and inflammatory conditions and continued to be suppressive in vivo (161). The requirement for antigen specificity of FoxP3 genetransferred cells and the dose of cells required for suppression, as well as persistence in vivo, are questions that still need to be addressed.

Another similar approach for engineering Treg specificity using TCR gene transfer has been shown to improve Treg potency, as observed in preclinical models for diabetes, transplantation tolerance, arthritis, and hemophilia A (61, 162-165). Engineered TCRs provide a viable alternative to redirect Treg specificity to a single antigenic epitope with a potentially high TCR affinity. However, this approach is HLA restricted and thus limits the number of patients to those with common HLA alleles.

Inspired by the clinical success of using CAR-T cells to treat certain types of cancers, a similar approach has been applied that engineers Tregs to express extracellular single-chain antigenbinding domains ( $\mathrm{scFv}$ ) fused to intracellular signaling molecules (Figure 2C). CARs can directly recognize their corresponding antigen irrespective of HLA. Further, issues such as TCR chain mispairing, which is a potential concern with TCR gene transfer, do not arise. At present, it is unclear how CAR-Tregs exert their suppressive effect and which cell populations they interact with. It has been postulated that the optimal activation of CAR-Tregs requires the presence of APCs (62). It is possible that CAR-Tregs recognize antigen that is immobilized on the surface of the APC, although molecular interactions or receptors that may be involved remain to be defined. The ability of CAR-Tregs to respond directly to soluble antigen or to recognize antigen bound to a $\mathrm{B}$-cell receptor (BCR) is also still an open question (Figure 2C). 


\section{A Ex vivo expanded polyclonal Treg}
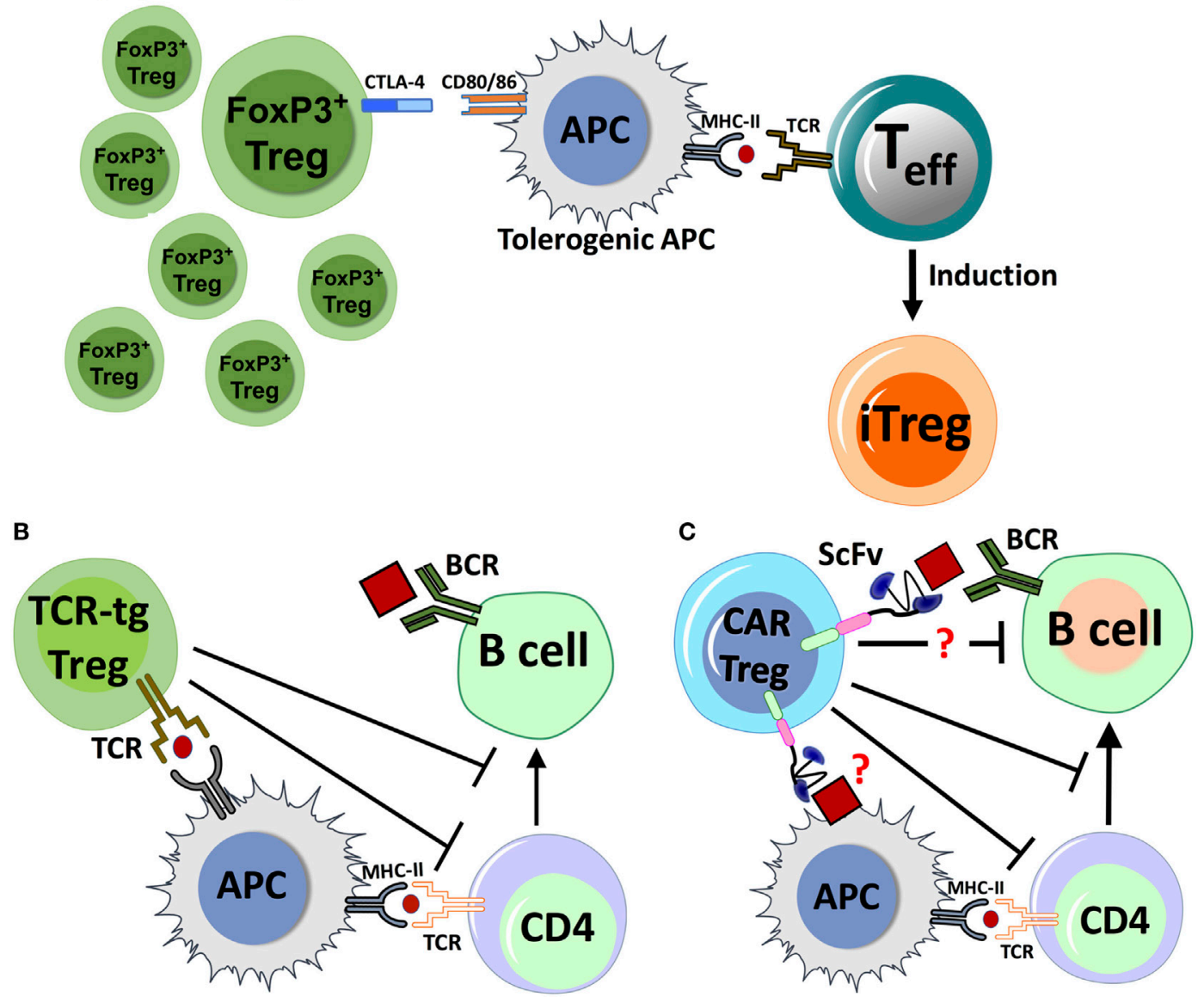

FIGURE 2 | Proposed mechanisms for immune suppression by adoptive transfer of polyclonal FoxP3+ regulatory T cell (Treg), chimeric antigen receptor (CAR)-Treg or TCR-transgenic (TCR-tg) Treg. (A) Adoptively transferred ex vivo expanded Treg with polyclonal specificity can interact with antigen-presenting cell (APC). Inhibitory receptors like CTLA-4 can compete with the costimulatory molecule CD28 to bind to CD80/86 receptors, and combined with other factors, it can lead to APC tolerization. Tolerogenic APCs interact with activated antigen-specific T effector ( $\left.T_{\text {eff }}\right)$ cells, which leads to conversion of $T_{\text {eff }}$ to induced Treg (iTreg). (B) Natural Treg engineered with TCR specificity for antigen (TCR-tg Treg) can recognize antigen presented by APCs, directly suppressing the APC's capacity to costimulate eff $_{\text {f }}$ cells. TCR-tg Treg can also directly inhibit CD4+ T helper cells, which in turn affects T cell help to antigen-specific B-cells. (C) Putative mechanisms for antigen recognition and suppression by CAR-Treg. CAR-Tregs may recognize either a B-cell bound antigenic epitope or antigen on the surface of APC, which can trigger the activation and proliferation of the CAR-Treg through transmembrane and intracellular-signaling domains. The mechanisms by which CAR-Tregs exert their suppressive effects are not clearly defined, but may include interactions with key cell types.

Chimeric antigen receptor regulatory $\mathrm{T}$ cells are being tested in preclinical models of EAE, allograft rejection, colitis, rheumatoid arthritis, and hemophilia A $(62,166-174)$. The first CAR-Treg trial, by the French company TxCell, for the prevention of transplant rejection is expected to commence in 2018. Such clinical trials will be able to address questions such as immunogenicity of the novel CAR molecule (175), or the possibility of cytokine release syndrome, which is a serious side effect of CAR-T cell treatments for cancer (176). Meanwhile, new CAR strategies are being developed to improve the specificity and function of CARmodified T cells/Tregs. For example, the transient expression of a CAR construct that recognizes the FITC molecule can be used to target Treg function to transplanted organs by binding to FITCconjugated monoclonal antibodies against donor $\mathrm{MHC}$ antigens (174). Alternatively, the surface expression of the antigenic domain, rather than the scFv, conjugated to primary and secondary signaling molecules, can bind the BCR of the corresponding antigen-specific B-cell, thus promoting B-cell depletion or suppression, as demonstrated in a model for autoimmunity and hemophilia A $(177,178)$.

\section{CHALLENGES AND FUTURE DIRECTIONS}

Beginning with the discovery in 1990 and 1995 that adoptively transferred $\mathrm{CD} 4{ }^{+} \mathrm{CD} 25^{+}$Tregs can maintain tolerance in an autoimmune animal model (179), the clinical prospects of Tregs have expanded in the past decade (36). It is apparent from studies with disease models and clinical trials that Treg-suppressive mechanisms can counter immune activation caused by gene replacement therapy. 
Although clinical trials using adoptively transferred Tregs to supplement gene therapy have not been attempted thus far, this review highlights several benefits for combining these two approaches. For example, existing obstacles faced in recent clinical trials such as unwanted immune responses to gene therapy and the inability to readminister vector could be mitigated by the codelivery of Treg with the vector. Adoptive immunotherapy with Tregs has shown clinical efficacy in autoimmune diseases such as T1D (which is characterized by a detrimental inflammatory response) and can tolerize against inflammatory reactions to a transplanted organ. We therefore propose that augmenting gene transfer applications, either by promoting the in vivo induction and expansion or Tregs or by immunomodulation with adoptively transferred Tregs can work synergistically and lead to successful gene transfer.

It is crucial, however, to emphasize the importance of good manufacturing practice-compliant cell therapy procedures, especially for the generation of polyclonal Tregs, which require dosing at larger cell numbers to reach therapeutic efficacy (180). A current challenge with using Tregs in the clinic is the need for the isolation and expansion of a pure population of functional and stable cells in sufficient numbers. FoxP3 is an intracellular marker and can be transiently expressed by activated $\mathrm{CD}^{+}$and $\mathrm{CD}^{+} \mathrm{T}$ cells. Optimization of cell sorting, such as employing double sorting of $\mathrm{CD} 4{ }^{+} \mathrm{CD} 25^{\mathrm{hi}} \mathrm{CD} 127^{\mathrm{lo}}$ cells can ensure increased purity of the starting population to help control for the outgrowth of effector T cells, which expand exponentially faster than Tregs in culture.

Regulatory $\mathrm{T}$ cell infusion may be beneficial not only in gene replacement settings to suppress capsid and transgene-specific immune responses but may also have the potential as adjunct therapy to prevent immune responses toward vector readministration. The formation of neutralizing antibodies constitutes

\section{REFERENCES}

1. Naldini L. Gene therapy returns to centre stage. Nature (2015) 526(7573): 351-60. doi:10.1038/nature 15818

2. Kumar SR, Markusic DM, Biswas M, High KA, Herzog RW. Clinical development of gene therapy: results and lessons from recent successes. Mol Ther Methods Clin Dev (2016) 3:16034. doi:10.1038/mtm.2016.34

3. Cavazzana-Calvo M, Hacein-Bey S, de Saint Basile G, Gross F, Yvon E, Nusbaum P, et al. Gene therapy of human severe combined immunodeficiency (SCID)-X1 disease. Science (2000) 288(5466):669-72. doi:10.1126/ science.288.5466.669

4. Maguire AM, Simonelli F, Pierce EA, Pugh EN Jr, Mingozzi F, Bennicelli J, et al. Safety and efficacy of gene transfer for Leber's congenital amaurosis. N Engl J Med (2008) 358(21):2240-8. doi:10.1056/NEJMoa0802315

5. Aiuti A, Cattaneo F, Galimberti S, Benninghoff U, Cassani B, Callegaro L, et al. Gene therapy for immunodeficiency due to adenosine deaminase deficiency. N Engl J Med (2009) 360(5):447-58. doi:10.1056/NEJMoa0805817

6. Cavazzana-Calvo M, Payen E, Negre O, Wang G, Hehir K, Fusil F, et al. Transfusion independence and HMGA2 activation after gene therapy of human beta-thalassaemia. Nature (2010) 467(7313):318-22. doi:10.1038/nature09328

7. Nathwani AC, Reiss UM, Tuddenham EG, Rosales C, Chowdary P, McIntosh J, et al. Long-term safety and efficacy of factor IX gene therapy in hemophilia B. N Engl J Med (2014) 371(21):1994-2004. doi:10.1056/NEJMoa1407309

8. Ribeil JA, Hacein-Bey-Abina S, Payen E, Magnani A, Semeraro M, Magrin E, et al. Gene therapy in a patient with sickle cell disease. N Engl J Med (2017) 376(9):848-55. doi:10.1056/NEJMoa1609677 a major obstacle to vector readministration, as they are elicited at high titers following gene transfer and can persist for years. Repeat administration of vector may be required when the gene product does not reach therapeutic levels, or when administered to pediatric patients, where an increasing organ turnover may limit the therapeutic dose over time. Successful gene therapy would expose the patient's immune system to the newly delivered vector and/or transgene, generating $B$ and $T$ cell responses that would limit the ability to readminister vector. Plasmapheresis and transient immunosuppression (anti-CD40 Ab, CTLA-4 Ig, highdose corticosteroids, rapamycin, rituximab, or combinations of these treatments) are currently being tested to allow for repeat injections (NCT02240407) $(76,113,181)$. The use of adoptive Treg therapy in these scenarios has not been tested, and thus it remains a possible combinatorial therapy product for blocking potential immune responses.

\section{AUTHOR CONTRIBUTIONS}

$\mathrm{MB}, \mathrm{SK}, \mathrm{CT}$, and RH made substantial contributions to the concept of this work, drafted, and made critical revisions and final approval. MB, SK, CT, and RH agreed to be accountable for all aspects of the work.

\section{FUNDING}

This work was supported by the National Institutes of Health, the National Institute of Allergy, and Infectious Diseases grant R01 AI51390 (RH), and the National Institutes of Health, National Heart, Lung, and Blood Institute grants R01 HL097088 (RH) and R01 HL131093 (RH and CT). MB received funding from the Bayer Hemophilia Awards Program (AWD00215).

9. Hauswirth WW, Aleman TS, Kaushal S, Cideciyan AV, Schwartz SB, Wang L, et al. Treatment of leber congenital amaurosis due to RPE65 mutations by ocular subretinal injection of adeno-associated virus gene vector: short-term results of a phase I trial. Hum Gene Ther (2008) 19(10):979-90. doi:10.1089/hum.2008.107

10. Assessment of adenoviral vector safety and toxicity: report of the National Institutes of Health Recombinant DNA Advisory Committee. Hum Gene Ther (2002) 13(1):3-13. doi:10.1089/10430340152712629

11. Kaplitt MG, Feigin A, Tang C, Fitzsimons HL, Mattis P, Lawlor PA, et al. Safety and tolerability of gene therapy with an adeno-associated virus (AAV) borne GAD gene for Parkinson's disease: an open label, phase I trial. Lancet (2007) 369(9579):2097-105. doi:10.1016/S0140-6736(07)60982-9

12. Bainbridge JW, Smith AJ, Barker SS, Robbie S, Henderson R, Balaggan K, et al. Effect of gene therapy on visual function in Leber's congenital amaurosis. N Engl J Med (2008) 358(21):2231-9. doi:10.1056/NEJMoa0802268

13. Wang L, Dobrzynski E, Schlachterman A, Cao O, Herzog RW. Systemic protein delivery by muscle-gene transfer is limited by a local immune response. Blood (2005) 105(11):4226-34. doi:10.1182/blood-2004-03-0848

14. Kaiser J. Gene therapy. Beta-thalassemia treatment succeeds, with a caveat. Science (2009) 326(5959):1468-9. doi:10.1126/science.326.5959.1468-b

15. Aiuti A, Biasco L, Scaramuzza S, Ferrua F, Cicalese MP, Baricordi C, et al. Lentiviral hematopoietic stem cell gene therapy in patients with Wiskott-Aldrich syndrome. Science (2013) 341(6148):1233151. doi:10.1126/ science. 1233151

16. Annoni A, Cantore A, Della Valle P, Goudy K, Akbarpour M, Russo F, et al. Liver gene therapy by lentiviral vectors reverses anti-factor IX pre-existing 
immunity in haemophilic mice. EMBO Mol Med (2013) 5(11):1684-97. doi:10.1002/emmm.201302857

17. Cantore A, Ranzani M, Bartholomae CC, Volpin M, Valle PD, Sanvito F, et al. Liver-directed lentiviral gene therapy in a dog model of hemophilia B. Sci Transl Med (2015) 7(277):277ra228. doi:10.1126/scitranslmed.aaa1405

18. Dismuke D, Samulski RJ. Hepatic gene therapy using lentiviral vectors: has safety been established? Hepatology (2013) 58(1):13-4. doi:10.1002/ hep. 26460

19. Abordo-Adesida E, Follenzi A, Barcia C, Sciascia S, Castro MG, Naldini L, et al. Stability of lentiviral vector-mediated transgene expression in the brain in the presence of systemic antivector immune responses. Hum Gene Ther (2005) 16(6):741-51. doi:10.1089/hum.2005.16.741

20. Fang $\mathrm{Y}$, Gong $\mathrm{X}, \mathrm{Xu} \mathrm{M}$, Zeng $\mathrm{F}$, Zhang J. A self-deletion lentiviral vector to reduce the risk of replication-competent virus formation. J Gene Med (2013) 15(2):102-12. doi:10.1002/jgm.2700

21. Brown BD, Sitia G, Annoni A, Hauben E, Sergi LS, Zingale A, et al. In vivo administration of lentiviral vectors triggers a type I interferon response that restricts hepatocyte gene transfer and promotes vector clearance. Blood (2007) 109(7):2797-805. doi:10.1182/blood-2006-10-049312

22. Breckpot K, Escors D, Arce F, Lopes L, Karwacz K, Van Lint S, et al. HIV-1 lentiviral vector immunogenicity is mediated by toll-like receptor 3 (TLR3) and TLR7. J Virol (2010) 84(11):5627-36. doi:10.1128/JVI.00014-10

23. Agudo J, Ruzo A, Kitur K, Sachidanandam R, Blander JM, Brown BD. A TLR and non-TLR mediated innate response to lentiviruses restricts hepatocyte entry and can be ameliorated by pharmacological blockade. Mol Ther (2012) 20(12):2257-67. doi:10.1038/mt.2012.150

24. Tripathy SK, Black HB, Goldwasser E, Leiden JM. Immune responses to transgene-encoded proteins limit the stability of gene expression after injection of replication-defective adenovirus vectors. Nat Med (1996) 2(5):545-50. doi:10.1038/nm0596-545

25. Yang Y, Jooss KU, Su Q, Ertl HC, Wilson JM. Immune responses to viral antigens versus transgene product in the elimination of recombinant adenovirus-infected hepatocytes in vivo. Gene Ther (1996) 3(2):137-44.

26. Muruve DA. The innate immune response to adenovirus vectors. Hum Gene Ther (2004) 15(12):1157-66. doi:10.1089/hum.2004.15.1157

27. Ledgerwood JE, DeZure AD, Stanley DA, Coates EE, Novik L, Enama ME, et al. Chimpanzee adenovirus vector Ebola vaccine. N Engl J Med (2017) 376(10):928-38. doi:10.1056/NEJMoa1410863

28. Alba R, Bosch A, Chillon M. Gutless adenovirus: last-generation adenovirus for gene therapy. Gene Ther (2005) 12(Suppl 1):S18-27. doi:10.1038/ sj.gt. 3302612

29. Muruve DA, Cotter MJ, Zaiss AK, White LR, Liu Q, Chan T, et al. Helper-dependent adenovirus vectors elicit intact innate but attenuated adaptive host immune responses in vivo. J Virol (2004) 78(11):5966-72. doi:10.1128/JVI.78.11.5966-5972.2004

30. Zaiss AK, Muruve DA. Immunity to adeno-associated virus vectors in animals and humans: a continued challenge. Gene Ther (2008) 15(11):808-16. doi:10.1038/gt.2008.54

31. Zhu J, Huang X, Yang Y. The TLR9-MyD88 pathway is critical for adaptive immune responses to adeno-associated virus gene therapy vectors in mice. J Clin Invest (2009) 119(8):2388-98. doi:10.1172/JCI37607

32. Rogers GL, Shirley JL, Zolotukhin I, Kumar SRP, Sherman A, Perrin GQ, et al. Plasmacytoid and conventional dendritic cells cooperate in crosspriming AAV capsid-specific CD8 ${ }^{+}$T cells. Blood (2017) 129(24):3184-95. doi:10.1182/blood-2016-11-751040

33. Manno CS, Pierce GF, Arruda VR, Glader B, Ragni M, Rasko JJ, et al. Successful transduction of liver in hemophilia by AAV-factor IX and limitations imposed by the host immune response. Nat Med (2006) 12(3):342-7. doi: $10.1038 / \mathrm{nm} 1358$

34. Mingozzi F, Maus MV, Hui DJ, Sabatino DE, Murphy SL, Rasko JE, et al. CD8(+) T-cell responses to adeno-associated virus capsid in humans. Nat Med (2007) 13(4):419-22. doi:10.1038/nm1549

35. Pien GC, Basner-Tschakarjan E, Hui DJ, Mentlik AN, Finn JD, Hasbrouck NC, et al. Capsid antigen presentation flags human hepatocytes for destruction after transduction by adeno-associated viral vectors. JClin Invest (2009) 119(6):1688-95. doi:10.1172/JCI36891

36. Nathwani AC, Tuddenham EG, Rangarajan S, Rosales C, McIntosh J, Linch DC, et al. Adenovirus-associated virus vector-mediated gene transfer in hemophilia B. NEngl J Med (2011) 365(25):2357-65. doi:10.1056/NEJMoa1108046
37. Sakaguchi S, Miyara M, Costantino CM, Hafler DA. FOXP3 ${ }^{+}$regulatory T cells in the human immune system. Nat Rev Immunol (2010) 10(7):490-500. doi: $10.1038 /$ nri2785

38. Afzali B, Lombardi G, Lechler RI, Lord GM. The role of T helper 17 (Th17) and regulatory $\mathrm{T}$ cells (Treg) in human organ transplantation and autoimmune disease. Clin Exp Immunol (2007) 148(1):32-46. doi:10.1111/j. 1365-2249.2007.03356.x

39. Mougiakakos D, Choudhury A, Lladser A, Kiessling R, Johansson CC. Regulatory T cells in cancer. Adv Cancer Res (2010) 107:57-117. doi:10.1016/ S0065-230X(10)07003-X

40. Tanaka A, Sakaguchi S. Regulatory T cells in cancer immunotherapy. Cell Res (2017) 27(1):109-18. doi:10.1038/cr.2016.151

41. Fontenot JD, Dooley JL, Farr AG, Rudensky AY. Developmental regulation of Foxp3 expression during ontogeny. J Exp Med (2005) 202(7):901-6. doi:10.1084/jem.20050784

42. Gregori S, Goudy KS, Roncarolo MG. The cellular and molecular mechanisms of immuno-suppression by human type 1 regulatory T cells. Front Immunol (2012) 3:30. doi:10.3389/fimmu.2012.00030

43. Gagliani N, Magnani CF, Huber S, Gianolini ME, Pala M, Licona-Limon P, et al. Coexpression of CD49b and LAG-3 identifies human and mouse T regulatory type 1 cells. Nat Med (2013) 19(6):739-46. doi:10.1038/ nm.3179

44. Chen ML, Yan BS, Bando Y, Kuchroo VK, Weiner HL. Latency-associated peptide identifies a novel $\mathrm{CD} 4^{+} \mathrm{CD} 25^{+}$regulatory T cell subset with TGFbetamediated function and enhanced suppression of experimental autoimmune encephalomyelitis. J Immunol (2008) 180(11):7327-37. doi:10.4049/ jimmunol.180.11.7327

45. Milpied P, Renand A, Bruneau J, Mendes-da-Cruz DA, Jacquelin S, Asnafi V, et al. Neuropilin-1 is not a marker of human Foxp3+ Treg. Eur J Immunol (2009) 39(6):1466-71. doi:10.1002/eji.200839040

46. Yadav M, Louvet C, Davini D, Gardner JM, Martinez-Llordella M, Bailey-Bucktrout S, et al. Neuropilin-1 distinguishes natural and inducible regulatory T cells among regulatory $\mathrm{T}$ cell subsets in vivo. J Exp Med (2012) 209(10):S1-19. doi:10.1084/jem.20120822

47. Bollyky PL, Falk BA, Long SA, Preisinger A, Braun KR, Wu RP, et al. CD44 costimulation promotes FoxP3 ${ }^{+}$regulatory $\mathrm{T}$ cell persistence and function via production of IL-2, IL-10, and TGF-beta. J Immunol (2009) 183(4):2232-41. doi:10.4049/jimmunol.0900191

48. Vien le TM, Abuoun M, Morrison V, Thomson N, Campbell JI, Woodward MJ, et al. Differential phenotypic and genotypic characteristics of qnrS1harboring plasmids carried by hospital and community commensal enterobacteria. Antimicrob Agents Chemother (2011) 55(4):1798-802. doi:10.1128/ AAC. $01200-10$

49. Deaglio S, Dwyer KM, Gao W, Friedman D, Usheva A, Erat A, et al. Adenosine generation catalyzed by $\mathrm{CD} 39$ and $\mathrm{CD} 73$ expressed on regulatory $\mathrm{T}$ cells mediates immune suppression. J Exp Med (2007) 204(6):1257-65. doi:10.1084/jem.20062512

50. Garin MI, Chu CC, Golshayan D, Cernuda-Morollon E, Wait R, Lechler RI. Galectin-1: a key effector of regulation mediated by CD4+CD25+ T cells. Blood (2007) 109(5):2058-65. doi:10.1182/blood-2006-04-016451

51. Kubach J, Lutter P, Bopp T, Stoll S, Becker C, Huter E, et al. Human $\mathrm{CD} 4{ }^{+} \mathrm{CD} 25^{+}$regulatory $\mathrm{T}$ cells: proteome analysis identifies galectin- 10 as a novel marker essential for their anergy and suppressive function. Blood (2007) 110(5):1550-8. doi:10.1182/blood-2007-01-069229

52. Tran DQ, Andersson J, Wang R, Ramsey H, Unutmaz D, Shevach EM. GARP (LRRC32) is essential for the surface expression of latent TGF-beta on platelets and activated FOXP3+ regulatory T cells. Proc Natl Acad Sci U S A (2009) 106(32):13445-50. doi:10.1073/pnas.0901944106

53. Edwards JP, Fujii H, Zhou AX, Creemers J, Unutmaz D, Shevach EM. Regulation of the expression of GARP/latent TGF-betal complexes on mouse $\mathrm{T}$ cells and their role in regulatory $\mathrm{T}$ cell and Th17 differentiation. J Immunol (2013) 190(11):5506-15. doi:10.4049/jimmunol.1300199

54. Wing K, Onishi Y, Prieto-Martin P, Yamaguchi T, Miyara M, Fehervari Z, et al. CTLA- 4 control over Foxp3 $3^{+}$regulatory T cell function. Science (2008) 322(5899):271-5. doi:10.1126/science.1160062

55. Shevach EM. Mechanisms of FoxP3 ${ }^{+}$T regulatory cell-mediated suppression. Immunity (2009) 30(5):636-45. doi:10.1016/j.immuni.2009.04.010

56. Verhagen J, Gabrysova L, Minaee S, Sabatos CA, Anderson G, Sharpe $\mathrm{AH}$, et al. Enhanced selection of $\mathrm{FoxP}^{+}$T-regulatory cells protects 
CTLA-4-deficient mice from CNS autoimmune disease. Proc Natl Acad Sci U S A (2009) 106(9):3306-11. doi:10.1073/pnas.0803186106

57. Qureshi OS, Zheng Y, Nakamura K, Attridge K, Manzotti C, Schmidt EM, et al. Trans-endocytosis of CD80 and CD86: a molecular basis for the cellextrinsic function of CTLA-4. Science (2011) 332(6029):600-3. doi:10.1126/ science. 1202947

58. Wing JB, Ise W, Kurosaki T, Sakaguchi S. Regulatory $\mathrm{T}$ cells control antigen-specific expansion of TFH cell number and humoral immune responses via the coreceptor CTLA-4. Immunity (2014) 41(6):1013-25. doi:10.1016/j.immuni.2014.12.006

59. Paterson AM, Lovitch SB, Sage PT, Juneja VR, Lee Y, Trombley JD, et al. Deletion of CTLA-4 on regulatory T cells during adulthood leads to resistance to autoimmunity. J Exp Med (2015) 212(10):1603-21. doi:10.1084/ jem.20141030

60. Sfikakis PP, Souliotis VL, Fragiadaki KG, Moutsopoulos HM, Boletis JN, Theofilopoulos AN. Increased expression of the FoxP3 functional marker of regulatory T cells following B cell depletion with rituximab in patients with lupus nephritis. Clin Immunol (2007) 123(1):66-73. doi:10.1016/j. clim.2006.12.006

61. Kim YC, Zhang AH, Su Y, Rieder SA, Rossi RJ, Ettinger RA, et al. Engineered antigen-specific human regulatory $\mathrm{T}$ cells: immunosuppression of FVIIIspecific T- and B-cell responses. Blood (2015) 125(7):1107-15. doi:10.1182/ blood-2014-04-566786

62. Yoon J, Schmidt A, Zhang AH, Konigs C, Kim YC, Scott DW. FVIIIspecific human chimeric antigen receptor T-regulatory cells suppress T- and B-cell responses to FVIII. Blood (2017) 129(2):238-45. doi:10.1182/ blood-2016-07-727834

63. Li MO, Rudensky AY. T cell receptor signalling in the control of regulatory T cell differentiation and function. Nat Rev Immunol (2016) 16(4):220-33. doi:10.1038/nri.2016.26

64. Collison LW, Workman CJ, Kuo TT, Boyd K, Wang Y, Vignali KM, et al. The inhibitory cytokine IL-35 contributes to regulatory T-cell function. Nature (2007) 450(7169):566-9. doi:10.1038/nature06306

65. Grossman WJ, Verbsky JW, Barchet W, Colonna M, Atkinson JP, Ley TJ. Human $\mathrm{T}$ regulatory cells can use the perforin pathway to cause autologous target cell death. Immunity (2004) 21(4):589-601. doi:10.1016/j. immuni.2004.09.002

66. Cobbold SP, Adams E, Farquhar CA, Nolan KF, Howie D, Lui KO, et al. Infectious tolerance via the consumption of essential amino acids and mTOR signaling. Proc Natl Acad Sci U S A (2009) 106(29):12055-60. doi:10.1073/ pnas.0903919106

67. Newton R, Priyadharshini B, Turka LA. Immunometabolism of regulatory T cells. Nat Immunol (2016) 17(6):618-25. doi:10.1038/ni.3466

68. Liang B, Workman C, Lee J, Chew C, Dale BM, Colonna L, et al. Regulatory $\mathrm{T}$ cells inhibit dendritic cells by lymphocyte activation gene-3 engagement of MHC class II. J Immunol (2008) 180(9):5916-26. doi:10.4049/ jimmunol.180.9.5916

69. Onishi Y, Fehervari Z, Yamaguchi T, Sakaguchi S. FoxP3 ${ }^{+}$natural regulatory $\mathrm{T}$ cells preferentially form aggregates on dendritic cells in vitro and actively inhibit their maturation. Proc Natl Acad Sci U S A (2008) 105(29):10113-8. doi:10.1073/pnas.0711106105

70. Boisgerault F, Mingozzi F. The skeletal muscle environment and its role in immunity and tolerance to AAV vector-mediated gene transfer. Curr Gene Ther (2015) 15(4):381-94. doi:10.2174/1566523215666150630121750

71. Mendell JR, Campbell K, Rodino-Klapac L, Sahenk Z, Shilling C, Lewis S, et al. Dystrophin immunity in Duchenne's muscular dystrophy. N Engl J Med (2010) 363(15):1429-37. doi:10.1056/NEJMoa1000228

72. Mendell JR, Rodino-Klapac LR, Rosales XQ, Coley BD, Galloway G, Lewis S, et al. Sustained alpha-sarcoglycan gene expression after gene transfer in limb-girdle muscular dystrophy, type 2D. Ann Neurol (2010) 68(5):629-38. doi:10.1002/ana.22251

73. Smith BK, Collins SW, Conlon TJ, Mah CS, Lawson LA, Martin AD, et al. Phase I/II trial of adeno-associated virus-mediated alpha-glucosidase gene therapy to the diaphragm for chronic respiratory failure in Pompe disease: initial safety and ventilatory outcomes. Hum Gene Ther (2013) 24(6):630-40. doi:10.1089/hum.2012.250

74. Byrne PI, Collins S, Mah CC, Smith B, Conlon T, Martin SD, et al. Phase I/II trial of diaphragm delivery of recombinant adeno-associated virus acid alpha-glucosidase (rAAaV1-CMV-GAA) gene vector in patients with Pompe disease. Hum Gene Ther Clin Dev (2014) 25(3):134-63. doi:10.1089/ humc.2014.2514

75. Cresawn KO, Fraites TJ, Wasserfall C, Atkinson M, Lewis M, Porvasnik S, et al. Impact of humoral immune response on distribution and efficacy of recombinant adeno-associated virus-derived acid alpha-glucosidase in a model of glycogen storage disease type II. Hum Gene Ther (2005) 16(1):68-80. doi:10.1089/hum.2005.16.68

76. Corti M, Elder M, Falk D, Lawson L, Smith B, Nayak S, et al. B-cell depletion is protective against anti-AAV capsid immune response: a human subject case study. Mol Ther Methods Clin Dev (2014) 1. doi:10.1038/mtm.2014.33

77. van Til NP, Stok M, Aerts Kaya FS, de Waard MC, Farahbakhshian E, Visser TP, et al. Lentiviral gene therapy of murine hematopoietic stem cells ameliorates the Pompe disease phenotype. Blood (2010) 115(26):5329-37. doi:10.1182/blood-2009-11-252874

78. Brantly ML, Chulay JD, Wang L, Mueller C, Humphries M, Spencer LT, et al. Sustained transgene expression despite $\mathrm{T}$ lymphocyte responses in a clinical trial of rAAV1-AAT gene therapy. Proc Natl Acad Sci U S A (2009) 106(38):16363-8. doi:10.1073/pnas.0904514106

79. Flotte TR, Trapnell BC, Humphries M, Carey B, Calcedo R, Rouhani F, et al. Phase 2 clinical trial of a recombinant adeno-associated viral vector expressing alpha1-antitrypsin: interim results. Hum Gene Ther (2011) 22(10):1239-47. doi:10.1089/hum.2011.053

80. Calcedo R, Somanathan S, Qin Q, Betts MR, Rech AJ, Vonderheide RH, et al. Class I-restricted T-cell responses to a polymorphic peptide in a gene therapy clinical trial for alpha-1-antitrypsin deficiency. Proc Natl Acad Sci U S A (2017) 114(7):1655-9. doi:10.1073/pnas.1617726114

81. Mueller C, Gernoux G, Gruntman AM, Borel F, Reeves EP, Calcedo R, et al. 5 year expression and neutrophil defect repair after gene therapy in alpha-1 antitrypsin deficiency. Mol Ther (2017) 25(6):1387-94. doi:10.1016/j. ymthe.2017.03.029

82. Mueller C, Chulay JD, Trapnell BC, Humphries M, Carey B, Sandhaus RA, et al. Human Treg responses allow sustained recombinant adeno-associated virus-mediated transgene expression. J Clin Invest (2013) 123(12):5310-8. doi:10.1172/JCI70314

83. Burzyn D, Kuswanto W, Kolodin D, Shadrach JL, Cerletti M, Jang Y, et al. A special population of regulatory $\mathrm{T}$ cells potentiates muscle repair. Cell (2013) 155(6):1282-95. doi:10.1016/j.cell.2013.10.054

84. Villalta SA, Rosenthal W, Martinez L, Kaur A, Sparwasser T, Tidball JG, et al. Regulatory $\mathrm{T}$ cells suppress muscle inflammation and injury in muscular dystrophy. Sci Transl Med (2014) 6(258):258ra142. doi:10.1126/ scitranslmed.3009925

85. Gross DA, Leboeuf M, Gjata B, Danos O, Davoust J. $\mathrm{CD} 4^{+} \mathrm{CD} 25^{+}$regulatory T cells inhibit immune-mediated transgene rejection. Blood (2003) 102(13):4326-8. doi:10.1182/blood-2003-05-1454

86. Tiegs G, Lohse AW. Immune tolerance: what is unique about the liver. J Autoimmun (2010) 34(1):1-6. doi:10.1016/j.jaut.2009.08.008

87. Kattenhorn LM, Tipper CH, Stoica L, Geraghty DS, Wright TL, Clark KR, et al. Adeno-associated virus gene therapy for liver disease. Hum Gene Ther (2016) 27(12):947-61. doi:10.1089/hum.2016.160

88. Herzog RW. A cure for hemophilia: the promise becomes a reality. Mol Ther (2016) 24(9):1503-4. doi:10.1038/mt.2016.169

89. Herzog RW. Complexity of immune responses to AAV transgene productsexample of factor IX. Cell Immunol (2017). doi:10.1016/j.cellimm.2017.05.006

90. Arruda VR, Samelson-Jones BJ. Gene therapy for immune tolerance induction in hemophilia with inhibitors. J Thromb Haemost (2016) 14(6):1121-34. doi:10.1111/jth.13331

91. Finn JD, Ozelo MC, Sabatino DE, Franck HW, Merricks EP, Crudele JM, et al. Eradication of neutralizing antibodies to factor VIII in canine hemophilia A after liver gene therapy. Blood (2010) 116(26):5842-8. doi:10.1182/ blood-2010-06-288001

92. Sack BK, Merchant S, Markusic DM, Nathwani AC, Davidoff AM, Byrne BJ, et al. Transient B cell depletion or improved transgene expression by codon optimization promote tolerance to factor VIII in gene therapy. PLoS One (2012) 7(5):e37671. doi:10.1371/journal.pone.0037671

93. Nichols T, Whitford MH, Arruda VR, Stedman HH, Kay MA, High KA. Translational data from AAV-mediated gene therapy of hemophilia B in dogs. Hum Gene Ther Clin Dev (2014). doi:10.1089/hum.2014.153 
94. Crudele JM, Finn JD, Siner JI, Martin NB, Niemeyer GP, Zhou S, et al. AAV liver expression of FIX-Padua prevents and eradicates FIX inhibitor without increasing thrombogenicity in hemophilia B dogs and mice. Blood (2015) 125(10):1553-61. doi:10.1182/blood-2014-07-588194

95. Mingozzi F, Chen Y, Murphy SL, Edmonson SC, Tai A, Price SD, et al. Pharmacological modulation of humoral immunity in a nonhuman primate model of AAV gene transfer for hemophilia B. Mol Ther (2012) 20(7):1410-6. doi:10.1038/mt.2012.84

96. Nayak S, Cao O, Hoffman BE, Cooper M, Zhou S, Atkinson MA, et al. Prophylactic immune tolerance induced by changing the ratio of antigenspecific effector to regulatory T cells. J Thromb Haemost (2009) 7(9):1523-32. doi:10.1111/j.1538-7836.2009.03548.x

97. Miao CH. Immunomodulation for inhibitors in hemophilia A: the important role of Treg cells. Expert Rev Hematol (2010) 3(4):469-83. doi:10.1586/ ehm.10.33

98. Sarkar D, Biswas M, Liao G, Seay HR, Perrin GQ, Markusic DM, et al. Ex vivo expanded autologous polyclonal regulatory $\mathrm{T}$ cells suppress inhibitor formation in hemophilia. Mol Ther Methods Clin Dev (2014) 1. doi:10.1038/ mtm. 2014.30

99. Biswas M, Sarkar D, Kumar SR, Nayak S, Rogers GL, Markusic DM, et al. Synergy between rapamycin and FLT3 ligand enhances plasmacytoid dendritic cell-dependent induction of $\mathrm{CD}^{+} \mathrm{CD} 25^{+} \mathrm{FoxP}^{+}$Treg. Blood (2015) 125(19):2937-47. doi:10.1182/blood-2014-09-599266

100. Dobrzynski E, Fitzgerald JC, Cao O, Mingozzi F, Wang L, Herzog RW. Prevention of cytotoxic T lymphocyte responses to factor IX-expressing hepatocytes by gene transfer-induced regulatory T cells. Proc Natl Acad Sci US A (2006) 103(12):4592-7. doi:10.1073/pnas.0508685103

101. Cao O, Dobrzynski E, Wang L, Nayak S, Mingle B, Terhorst C, et al. Induction and role of regulatory $\mathrm{CD} 4{ }^{+} \mathrm{CD} 25^{+} \mathrm{T}$ cells in tolerance to the transgene product following hepatic in vivo gene transfer. Blood (2007) 110(4):1132-40. doi:10.1182/blood-2007-02-073304

102. Mingozzi F, Hasbrouck NC, Basner-Tschakarjan E, Edmonson SA, Hui DJ, Sabatino DE, et al. Modulation of tolerance to the transgene product in a nonhuman primate model of AAV-mediated gene transfer to liver. Blood (2007) 110(7):2334-41. doi:10.1182/blood-2007-03-080093

103. Luth S, Huber S, Schramm C, Buch T, Zander S, Stadelmann C, et al. Ectopic expression of neural autoantigen in mouse liver suppresses experimental autoimmune neuroinflammation by inducing antigen-specific Tregs. J Clin Invest (2008) 118(10):3403-10. doi:10.1172/JCI32132

104. Keeler GD, Kumar S, Palaschak B, Silverberg EL, Markusic DM, Jones NT, et al. Gene therapy-induced antigen-specific Tregs inhibit neuro-inflammation and reverse disease in a mouse model of multiple sclerosis. Mol Ther (2017). doi:10.1016/j.ymthe.2017.09.001

105. Akbarpour M, Goudy KS, Cantore A, Russo F, Sanvito F, Naldini L, et al. Insulin B chain 9-23 gene transfer to hepatocytes protects from type 1 diabetes by inducing Ag-specific FoxP3+ Tregs. Sci Transl Med (2015) 7(289):289ra281. doi:10.1126/scitranslmed.aaa3032

106. Thomson AW, Turnquist HR, Raimondi G. Immunoregulatory functions of mTOR inhibition. Nat Rev Immunol (2009) 9(5):324-37. doi:10.1038/nri2546

107. Hackstein H, Taner T, Zahorchak AF, Morelli AE, Logar AJ, Gessner A, et al. Rapamycin inhibits IL-4-induced dendritic cell maturation in vitro and dendritic cell mobilization and function in vivo. Blood (2003) 101(11):4457-63. doi:10.1182/blood-2002-11-3370

108. Delgoffe GM, Kole TP, Zheng Y, Zarek PE, Matthews KL, Xiao B, et al. The mTOR kinase differentially regulates effector and regulatory $\mathrm{T}$ cell lineage commitment. Immunity (2009) 30(6):832-44. doi:10.1016/j.immuni. 2009.04.014

109. Battaglia M, Stabilini A, Roncarolo MG. Rapamycin selectively expands $\mathrm{CD}^{+}{ }^{+} \mathrm{CD} 25^{+} \mathrm{FoxP}^{+}$regulatory T cells. Blood (2005) 105(12):4743-8. doi:10.1182/blood-2004-10-3932

110. Zeiser R, Leveson-Gower DB, Zambricki EA, Kambham N, Beilhack A, Loh J, et al. Differential impact of mammalian target of rapamycin inhibition on $\mathrm{CD} 4{ }^{+} \mathrm{CD} 25^{+} \mathrm{Foxp}^{+}$regulatory $\mathrm{T}$ cells compared with conventional $\mathrm{CD}^{+} \mathrm{T}$ cells. Blood (2008) 111(1):453-62. doi:10.1182/blood-200706-094482

111. Miao $\mathrm{CH}$. Tilt balance towards regulation: evolving new strategy for treatment of hemophilia inhibitors. J Thromb Haemost (2011) 9(8):1521-3. doi:10.1111/j.1538-7836.2011.04391.x
112. Nayak S, Sarkar D, Perrin GQ, Moghimi B, Hoffman BE, Zhou S, et al. Prevention and reversal of antibody responses against factor IX in gene therapy for hemophilia B. Front Microbiol (2011) 2:244. doi:10.3389/ fmicb.2011.00244

113. Corti M, Cleaver B, Clement N, Conlon TJ, Faris KJ, Wang G, et al. Evaluation of readministration of a recombinant adeno-associated virus vector expressing acid alpha-glucosidase in Pompe disease: preclinical to clinical planning. Hum Gene Ther Clin Dev (2015) 26(3):185-93. doi:10.1089/humc. 2015.068

114. Herzog RW, Nichols TC, Su J, Zhang B, Sherman A, Merricks EP, et al. Oral tolerance induction in hemophilia B dogs fed with transplastomic lettuce. Mol Ther (2017) 25(2):512-22. doi:10.1016/j.ymthe.2016.11.009

115. Coombes JL, Siddiqui KR, Arancibia-Carcamo CV, Hall J, Sun CM, Belkaid Y, et al. A functionally specialized population of mucosal $\mathrm{CD}_{103^{+}} \mathrm{DCs}$ induces FoxP3 ${ }^{+}$regulatory $\mathrm{T}$ cells via a TGF-beta and retinoic aciddependent mechanism. J Exp Med (2007) 204(8):1757-64. doi:10.1084/ jem. 20070590

116. Wang X, Sherman A, Liao G, Leong KW, Daniell H, Terhorst C, et al. Mechanism of oral tolerance induction to therapeutic proteins. Adv Drug Deliv Rev (2013) 65(6):759-73. doi:10.1016/j.addr.2012.10.013

117. Wang X, Su J, Sherman A, Rogers GL, Liao G, Hoffman BE, et al. Plant-based oral tolerance to hemophilia therapy employs a complex immune regulatory response including $\mathrm{LAP}^{+} \mathrm{CD}^{+} \mathrm{T}$ cells. Blood (2015) 125(15):2418-27. doi:10.1182/blood-2014-08-597070

118. Hadis U, Wahl B, Schulz O, Hardtke-Wolenski M, Schippers A, Wagner N, et al. Intestinal tolerance requires gut homing and expansion of FoxP3 ${ }^{+}$ regulatory $\mathrm{T}$ cells in the lamina propria. Immunity (2011) 34(2):237-46. doi:10.1016/j.immuni.2011.01.016

119. Hardet R, Chevalier B, Dupaty L, Naimi Y, Riou G, Drouot L, et al. Oral-tolerization prevents immune responses and improves transgene persistence following gene transfer mediated by adeno-associated viral vector. Mol Ther (2016) 24(1):87-95. doi:10.1038/mt.2015.146

120. June $\mathrm{CH}$, Blazar BR. Clinical application of expanded $\mathrm{CD} 4^{+} 25^{+}$cells. Semin Immunol (2006) 18(2):78-88. doi:10.1016/j.smim.2006.01.006

121. Juvet SC, Whatcott AG, Bushell AR, Wood KJ. Harnessing regulatory T cells for clinical use in transplantation: the end of the beginning. Am J Transplant (2014) 14(4):750-63. doi:10.1111/ajt.12647

122. Hippen KL, Merkel SC, Schirm DK, Sieben CM, Sumstad D, Kadidlo DM, et al. Massive ex vivo expansion of human natural regulatory T cells (T(regs)) with minimal loss of in vivo functional activity. Sci Transl Med (2011) 3(83):83ra41. doi:10.1126/scitranslmed.3001809

123. Cherai M, Hamel Y, Baillou C, Touil S, Guillot-Delost M, Charlotte F, et al. Generation of human alloantigen-specific regulatory $\mathrm{T}$ cells under good manufacturing practice-compliant conditions for cell therapy. Cell Transplant (2015) 24(12):2527-40. doi:10.3727/096368914X683566

124. Gregori S, Tomasoni D, Pacciani V, Scirpoli M, Battaglia M, Magnani CF, et al. Differentiation of type $1 \mathrm{~T}$ regulatory cells $(\mathrm{Tr} 1)$ by tolerogenic DC-10 requires the IL-10-dependent ILT4/HLA-G pathway. Blood (2010) 116(6): 935-44. doi:10.1182/blood-2009-07-234872

125. Petrelli A, Tresoldi E, Mfarrej BG, Paganelli A, Spotti D, Caldara R, et al. Generation of donor-specific $\mathrm{T}$ regulatory type 1 cells from patients on dialysis for cell therapy after kidney transplantation. Transplantation (2015) 99(8):1582-9. doi:10.1097/TP.0000000000000751

126. Mfarrej B, Tresoldi E, Stabilini A, Paganelli A, Caldara R, Secchi A, et al. Generation of donor-specific $\operatorname{Tr} 1$ cells to be used after kidney transplantation and definition of the timing of their in vivo infusion in the presence of immunosuppression. J Transl Med (2017) 15(1):40. doi:10.1186/ s12967-017-1133-8

127. Brunstein CG, Miller JS, Cao Q, McKenna DH, Hippen KL, Curtsinger J, et al. Infusion of ex vivo expanded T regulatory cells in adults transplanted with umbilical cord blood: safety profile and detection kinetics. Blood (2011) 117(3):1061-70. doi:10.1182/blood-2010-07-293795

128. Di Ianni M, Falzetti F, Carotti A, Terenzi A, Castellino F, Bonifacio E, et al. Tregs prevent GVHD and promote immune reconstitution in HLAhaploidentical transplantation. Blood (2011) 117(14):3921-8. doi:10.1182/ blood-2010-10-311894

129. Martelli MF, Di Ianni M, Ruggeri L, Falzetti F, Carotti A, Terenzi A, et al. HLA-haploidentical transplantation with regulatory and conventional T-cell 
adoptive immunotherapy prevents acute leukemia relapse. Blood (2014) 124(4):638-44. doi:10.1182/blood-2014-03-564401

130. Brunstein CG, Miller JS, McKenna DH, Hippen KL, DeFor TE, Sumstad D, et al. Umbilical cord blood-derived T regulatory cells to prevent GVHD: kinetics, toxicity profile, and clinical effect. Blood (2016) 127(8):1044-51. doi:10.1182/blood-2015-06-653667

131. Bacchetta R, Lucarelli B, Sartirana C, Gregori S, Lupo Stanghellini MT, Miqueu P, et al. Immunological outcome in haploidentical-HSC transplanted patients treated with IL-10-anergized donor T cells. Front Immunol (2014) 5:16. doi:10.3389/fimmu.2014.00016

132. Matsuoka K, Koreth J, Kim HT, Bascug G, McDonough S, Kawano Y, et al. Low-dose interleukin-2 therapy restores regulatory $\mathrm{T}$ cell homeostasis in patients with chronic graft-versus-host disease. Sci Transl Med (2013) 5(179):179ra143. doi:10.1126/scitranslmed.3005265

133. Kennedy-Nasser AA, Ku S, Castillo-Caro P, Hazrat Y, Wu MF, Liu H, et al. Ultra low-dose IL-2 for GVHD prophylaxis after allogeneic hematopoietic stem cell transplantation mediates expansion of regulatory $\mathrm{T}$ cells without diminishing antiviral and antileukemic activity. Clin Cancer Res (2014) 20(8):2215-25. doi:10.1158/1078-0432.CCR-13-3205

134. Koreth J, Kim HT, Jones KT, Lange PB, Reynolds CG, Chammas MJ, et al. Efficacy, durability, and response predictors of low-dose interleukin-2 therapy for chronic graft-versus-host disease. Blood (2016) 128(1):130-7. doi:10.1182/blood-2016-02-702852

135. Todo S, Yamashita K, Goto R, Zaitsu M, Nagatsu A, Oura T, et al. A pilot study of operational tolerance with a regulatory T-cell-based cell therapy in living donor liver transplantation. Hepatology (2016) 64(2):632-43. doi:10.1002/ hep. 28459

136. Geissler EK. The ONE study compares cell therapy products in organ transplantation: introduction to a review series on suppressive monocytederived cells. Transplant Res (2012) 1(1):11. doi:10.1186/2047-1440-1-11

137. Marek-Trzonkowska N, Mysliwiec M, Dobyszuk A, Grabowska M, Derkowska I, Juscinska J, et al. Therapy of type 1 diabetes with CD4(+) $\mathrm{CD} 25$ (high)CD127-regulatory $\mathrm{T}$ cells prolongs survival of pancreatic islets-results of one year follow-up. Clin Immunol (2014) 153(1):23-30. doi:10.1016/j.clim.2014.03.016

138. Pham MN, von Herrath MG, Vela JL. Antigen-specific regulatory T cells and low dose of IL-2 in treatment of type 1 diabetes. Front Immunol (2015) 6:651. doi:10.3389/fimmu.2015.00651

139. Bluestone JA, Buckner JH, Fitch M, Gitelman SE, Gupta S, Hellerstein MK, et al. Type 1 diabetes immunotherapy using polyclonal regulatory $\mathrm{T}$ cells. Sci Transl Med (2015) 7(315):315ra189. doi:10.1126/scitranslmed.aad4134

140. Kumar SR, Hoffman BE, Terhorst C, de Jong YP, Herzog RW. The balance between $\mathrm{CD} 8{ }^{+} \mathrm{T}$ cell-mediated clearance of AAV-encoded antigen in the liver and tolerance is dependent on the vector dose. Mol Ther (2017) 25(4):880-91. doi:10.1016/j.ymthe.2017.02.014

141. Greig JA, Wang Q, Reicherter AL, Chen SJ, Hanlon AL, Tipper CH, et al. Characterization of adeno-associated viral vector-mediated human factor VIII gene therapy in hemophilia A mice. Hum Gene Ther (2017) 28(5): 392-402. doi:10.1089/hum.2016.128

142. Annoni A, Brown BD, Cantore A, Sergi LS, Naldini L, Roncarolo MG. In vivo delivery of a microRNA-regulated transgene induces antigen-specific regulatory T cells and promotes immunologic tolerance. Blood (2009) 114(25):5152-61. doi:10.1182/blood-2009-04-214569

143. Merlin S, Cannizzo ES, Borroni E, Bruscaggin V, Schinco P, Tulalamba W, et al. A novel platform for immune tolerance induction in hemophilia A mice. Mol Ther (2017) 25(8):1815-30. doi:10.1016/j.ymthe.2017.04.029

144. Miao CH, Harmeling BR, Ziegler SF, Yen BC, Torgerson T, Chen L, et al. $\mathrm{CD}^{+} \mathrm{FOXP}^{+}$regulatory $\mathrm{T}$ cells confer long-term regulation of factor VIII-specific immune responses in plasmid-mediated gene therapytreated hemophilia mice. Blood (2009) 114(19):4034-44. doi:10.1182/ blood-2009-06-228155

145. Chai JG, Coe D, Chen D, Simpson E, Dyson J, Scott D. In vitro expansion improves in vivo regulation by $\mathrm{CD} 4{ }^{+} \mathrm{CD} 25^{+}$regulatory T cells. J Immunol (2008) 180(2):858-69. doi:10.4049/jimmunol.180.2.858

146. Schmitt EG, Williams CB. Generation and function of induced regulatory T cells. Front Immunol (2013) 4:152. doi:10.3389/fimmu.2013.00152

147. Tang Q, Henriksen KJ, Bi M, Finger EB, Szot G, Ye J, et al. In vitro-expanded antigen-specific regulatory $\mathrm{T}$ cells suppress autoimmune diabetes. J Exp Med (2004) 199(11):1455-65. doi:10.1084/jem.20040139
148. Golshayan D, Jiang S, Tsang J, Garin MI, Mottet C, Lechler RI. In vitroexpanded donor alloantigen-specific $\mathrm{CD} 4{ }^{+} \mathrm{CD} 25^{+}$regulatory $\mathrm{T}$ cells promote experimental transplantation tolerance. Blood (2007) 109(2):827-35. doi:10.1182/blood-2006-05-025460

149. Sagoo P, Ali N, Garg G, Nestle FO, Lechler RI, Lombardi G. Human regulatory $\mathrm{T}$ cells with alloantigen specificity are more potent inhibitors of alloimmune skin graft damage than polyclonal regulatory T cells. Sci Transl Med (2011) 3(83):83ra42. doi:10.1126/scitranslmed.3002076

150. Veerapathran A, Pidala J, Beato F, Yu XZ, Anasetti C. Ex vivo expansion of human Tregs specific for alloantigens presented directly or indirectly. Blood (2011) 118(20):5671-80. doi:10.1182/blood-2011-02-337097

151. Safinia N, Vaikunthanathan T, Fraser H, Thirkell S, Lowe K, Blackmore L, et al. Successful expansion of functional and stable regulatory $\mathrm{T}$ cells for immunotherapy in liver transplantation. Oncotarget (2016) 7(7):7563-77. doi:10.18632/oncotarget.6927

152. Verma ND, Hall BM, Plain KM, Robinson CM, Boyd R, Tran GT, et al. Interleukin-12 (IL-12p70) promotes induction of highly potent Th1-like $\mathrm{CD} 4(+) \mathrm{CD} 25(+) \mathrm{T}$ regulatory cells that inhibit allograft rejection in unmodified recipients. Front Immunol (2014) 5:190. doi:10.3389/fimmu. 2014.00190

153. Porter DL, Levine BL, Kalos M, Bagg A, June CH. Chimeric antigen receptor-modified T cells in chronic lymphoid leukemia. N Engl J Med (2011) 365(8):725-33. doi:10.1056/NEJMoa1103849

154. Brentjens RJ, Davila ML, Riviere I, Park J, Wang X, Cowell LG, et al. CD19-targeted T cells rapidly induce molecular remissions in adults with chemotherapy-refractory acute lymphoblastic leukemia. Sci Transl Med (2013) 5(177):177ral38. doi:10.1126/scitranslmed.3005930

155. Maude SL, Frey N, Shaw PA, Aplenc R, Barrett DM, Bunin NJ, et al. Chimeric antigen receptor T cells for sustained remissions in leukemia. $N$ Engl J Med (2014) 371(16):1507-17. doi:10.1056/NEJMoa1407222

156. Lee DW, Kochenderfer JN, Stetler-Stevenson M, Cui YK, Delbrook C, Feldman SA, et al. T cells expressing CD19 chimeric antigen receptors for acute lymphoblastic leukaemia in children and young adults: a phase 1 dose-escalation trial. Lancet (2015) 385(9967):517-28. doi:10.1016/ S0140-6736(14)61403-3

157. Hoggatt J. Gene therapy for "Bubble Boy". Disease Cell (2016) 166(2):263. doi:10.1016/j.cell.2016.06.049

158. Hori S, Nomura T, Sakaguchi S. Control of regulatory T cell development by the transcription factor Foxp3. Science (2003) 299(5609):1057-61. doi:10.1126/science.1079490

159. Andersen KG, Butcher T, Betz AG. Specific immunosuppression with inducible FoxP3-transduced polyclonal T cells. PLoS Biol (2008) 6(11):e276. doi:10.1371/journal.pbio.0060276

160. Beavis PA, Gregory B, Green P, Cribbs AP, Kennedy A, Amjadi P, et al. Resistance to regulatory $\mathrm{T}$ cell-mediated suppression in rheumatoid arthritis can be bypassed by ectopic foxp 3 expression in pathogenic synovial T cells. Proc Natl Acad Sci U S A (2011) 108(40):16717-22. doi:10.1073/ pnas. 1112722108

161. Passerini L, Rossi Mel E, Sartirana C, Fousteri G, Bondanza A, Naldini L, et al. CD4(+) T cells from IPEX patients convert into functional and stable regulatory T cells by FOXP3 gene transfer. Sci Transl Med (2013) 5(215):215ra174. doi:10.1126/scitranslmed.3007320

162. Tsang JY, Tanriver Y, Jiang S, Xue SA, Ratnasothy K, Chen D, et al. Conferring indirect allospecificity on $\mathrm{CD} 4{ }^{+} \mathrm{CD} 25^{+}$Tregs by TCR gene transfer favors transplantation tolerance in mice. JClin Invest (2008) 118(11):3619-28. doi:10.1172/JCI33185

163. Wright GP, Notley CA, Xue SA, Bendle GM, Holler A, Schumacher TN, et al. Adoptive therapy with redirected primary regulatory $\mathrm{T}$ cells results in antigen-specific suppression of arthritis. Proc Natl Acad Sci U S A (2009) 106(45):19078-83. doi:10.1073/pnas.0907396106

164. Brusko TM, Koya RC, Zhu S, Lee MR, Putnam AL, McClymont SA, et al. Human antigen-specific regulatory $\mathrm{T}$ cells generated by $\mathrm{T}$ cell receptor gene transfer. PLoS One (2010) 5(7):e11726. doi:10.1371/journal.pone.0011726

165. Hull CM, Nickolay LE, Estorninho M, Richardson MW, Riley JL, Peakman M, et al. Generation of human islet-specific regulatory T cells by TCR gene transfer. J Autoimmun (2017) 79:63-73. doi:10.1016/j.jaut.2017.01.001

166. Mekala DJ, Geiger TL. Immunotherapy of autoimmune encephalomyelitis with redirected $\mathrm{CD}^{+}{ }^{+} \mathrm{CD} 25^{+} \mathrm{T}$ lymphocytes. Blood (2005) 105(5):2090-2. doi:10.1182/blood-2004-09-3579 
167. Elinav E, Adam N, Waks T, Eshhar Z. Amelioration of colitis by genetically engineered murine regulatory $\mathrm{T}$ cells redirected by antigen-specific chimeric receptor. Gastroenterology (2009) 136(5):1721-31. doi:10.1053/j. gastro.2009.01.049

168. Fransson M, Piras E, Burman J, Nilsson B, Essand M, Lu B, et al. CAR/FoxP3engineered $\mathrm{T}$ regulatory cells target the CNS and suppress EAE upon intranasal delivery. J Neuroinflammation (2012) 9:112. doi:10.1186/1742-2094-9-112

169. Blat D, Zigmond E, Alteber Z, Waks T, Eshhar Z. Suppression of murine colitis and its associated cancer by carcinoembryonic antigen-specific regulatory T cells. Mol Ther (2014) 22(5):1018-28. doi:10.1038/mt.2014.41

170. MacDonald KG, Hoeppli RE, Huang Q, Gillies J, Luciani DS, Orban PC, et al. Alloantigen-specific regulatory $\mathrm{T}$ cells generated with a chimeric antigen receptor. J Clin Invest (2016) 126(4):1413-24. doi:10.1172/JCI82771

171. Raffin C. Development of citrullinated-vimentin-specific CAR for targeting Tregs to treat autoimmune rheumatoid arthritis. J Immunol (2016) 196(1 Suppl):210.219.

172. Boardman DA, Philippeos C, Fruhwirth GO, Ibrahim MA, Hannen RF, Cooper D, et al. Expression of a chimeric antigen receptor specific for donor HLA class I enhances the potency of human regulatory T cells in preventing human skin transplant rejection. Am J Transplant (2017) 17(4):931-43. doi:10.1111/ajt.14185

173. Noyan F, Zimmermann K, Hardtke-Wolenski M, Knoefel A, Schulde E, Geffers R, et al. Prevention of allograft rejection by use of regulatory T cells with an MHC-specific chimeric antigen receptor. Am J Transplant (2017) 17(4):917-30. doi:10.1111/ajt.14175

174. Pierini A, Iliopoulou BP, Peiris H, Perez-Cruz M, Baker J, Hsu K, et al. $\mathrm{T}$ cells expressing chimeric antigen receptor promote immune tolerance. JCI Insight (2017) 2(20). doi:10.1172/jci.insight.92865

175. Dotti G, Gottschalk S, Savoldo B, Brenner MK. Design and development of therapies using chimeric antigen receptor-expressing T cells. Immunol Rev (2014) 257(1):107-26. doi:10.1111/imr.12131
176. Maude SL, Barrett D, Teachey DT, Grupp SA. Managing cytokine release syndrome associated with novel T cell-engaging therapies. Cancer J (2014) 20(2):119-22. doi:10.1097/PPO.0000000000000035

177. Ellebrecht CT, Bhoj VG, Nace A, Choi EJ, Mao X, Cho MJ, et al. Reengineering chimeric antigen receptor $\mathrm{T}$ cells for targeted therapy of autoimmune disease. Science (2016) 353(6295):179-84. doi:10.1126/science. aaf6756

178. Zhang AH, Yoon JH, Kim YC, Scott DW. Targeting FVIII-specific B cells using BAR-transduced regulatory T cells. Blood (2016) 128(22):329.

179. Hall BM, Pearce NW, Gurley KE, Dorsch SE. Specific unresponsiveness in rats with prolonged cardiac allograft survival after treatment with cyclosporine. III. Further characterization of the CD4+ suppressor cell and its mechanisms of action. J Exp Med (1990) 171(1):141-57. doi:10.1084/jem.171.1.141

180. Parmar S, Shpall EJ. Treg adoptive therapy: is more better? Blood (2016) 127(8):962-3. doi:10.1182/blood-2015-12-682492

181. Lorain S, Gross DA, Goyenvalle A, Danos O, Davoust J, Garcia L. Transient immunomodulation allows repeated injections of AAV1 and correction of muscular dystrophy in multiple muscles. Mol Ther (2008) 16(3):541-7. doi:10.1038/sj.mt.6300377

Conflict of Interest Statement: The authors declare that the research was conducted in the absence of any commercial or financial relationships that could be construed as a potential conflict of interest.

Copyright (c) 2018 Biswas, Kumar, Terhorst and Herzog. This is an open-access article distributed under the terms of the Creative Commons Attribution License (CC BY). The use, distribution or reproduction in other forums is permitted, provided the original author(s) and the copyright owner are credited and that the original publication in this journal is cited, in accordance with accepted academic practice. No use, distribution or reproduction is permitted which does not comply with these terms. 